\title{
Tree Cover on Cattle Farms in the Southeast Region of Guatemala
}

\author{
Jennifer Solis ${ }^{1,}$ ", Cristóbal Villanueva ${ }^{2}$, Guillermo Detlefsen ${ }^{2}$, Christian Brenes ${ }^{3}$, Sergio Vilchez ${ }^{4}$ \\ ${ }^{1}$ Agroforestry and Sustainable Agriculture, Tropical Agricultural Research and Higher Education Center (CATIE), Turrialba, Costa Rica \\ ${ }^{2}$ Agroforestry and Sustainable Agriculture Program, CATIE, Turrialba, Costa Rica \\ ${ }^{3}$ Forest, Biodiversity and Climate Change Program, CATIE, Turrialba, Costa Rica \\ ${ }^{4}$ Unit of Biostatistics, CATIE, Turrialba, Costa Rica
}

Email address:

jennifer.solis@catie.ac.cr(J. Solis),cvillanu@catie.ac.cr(C. Villanueva),gdetlef@catie.ac.cr(G. Detlefsen), christian.brenes@catie.ac.cr(C. Brenes),svilchez@catie.ac.cr(S. Vilchez)

${ }^{*}$ Corresponding author

\section{To cite this article:}

Jennifer Solis, Cristóbal Villanueva, Guillermo Detlefsen, Christian Brenes, Sergio Vilchez. Tree Cover on Cattle Farms in the Southeast Region of Guatemala. American Journal of Agriculture and Forestry. Vol. 7, No. 2, 2019, pp. 66-77. doi: 10.11648/j.ajaf.20190702.14

Received: February 26, 2019; Accepted: April 9, 2019; Published: May 7, 2019

\begin{abstract}
Often livestock activity is related to deforestation and loss of natural resources such as soil and water quality and quantity. The strategies that come from this perception seek the minimization of livestock effect of greenhouse gas emissions into the environment. Silvopastoral systems is been used as an alternative to increase tree cover on livestock farms, mitigate the effects of climate change, and make farmers more resilient to these. Tree cover plays an important role inside of this system, they can help with the optimization of the land use on the farm and it provides socioeconomical and environmental benefits to the farmers. Therefore, the objective of this study was to characterize livestock farms and the floristic composition of tree cover in the southeast region of Guatemala. This region belongs to the dry corridor of Central America and present high vulnerability to drought. Thirty farms were selected using seven criteria, on each farms a socioeconomical survey was applied to recollect biophysical, socioeconomical and productive information. Two groups of farms were identified: 1) farms with high level technological innovation (HLTI) and 2) farms with low level of technological innovation (LLTI). Tree data were obtained from individuals with diameter above breast height (DBH) of $>5 \mathrm{~cm}$. Composition, richness and abundance of tree species were evaluated using Q-Hill Diversity Index. Seven land uses were identified: scattered trees in paddocks, natural forest, agrisilvicultural systems, fodder banks, forest plantations, riparian forest and living fences. Study area were 790 ha in which there were 143 plots distributed randomly, living fences were present in $1.691 \mathrm{~km}(169.1 \mathrm{ha})$ with 44 transects. A total of 4,678 trees, from 37 families and 83 species, were found in the area. The most abundant families were Fabaceae and Pinaceae. The most common tree species for timber were Pinus spp and Quercus spp and for non-timber were Gliricidia sepium and Acacia pennatula. It was found that $77.27 \%$ of the total inventory is dominated by ten species. We conclude that farmers consider tree cover of importance, this is reflected in the $29 \%$ of tree cover found inside of natural forests, $26.2 \%$ in scattered trees in paddocks and $7.9 \%$ in forest plantations. There were marked differences of richness by individuals, density of species accumulated by land use and diametrical class.
\end{abstract}

Keywords: Dry Region, Floristic Composition, Livestock Farm Typologies, Richness and Abundance of Species, Silvopastoral Systems

\section{Introduction}

The expansion of livestock systems is becoming increasingly visible in the countries of Central America, where certain part of forests are being lost each year because of this productive activity, and in turn increases the pressure on natural resources and the livelihoods of small farmers. Deforestation and forest degradation are among the world 
most pressing land-change problems [1]. In 1990, the world had 4,128 million ha of forest, and by 2015, this area had decreased to 3,999 million ha. It is estimated that Guatemala forest cover in 2006 was 3.87 million ha and that for 2010 was 3.72 million ha, of which 1.94 million ha were in protected areas and 1.77 million ha were outside protected areas [2]. In relative terms the loss of forest has occurred in broadleaved, followed by mixed, coniferous and mangrove forest [3].

Feed crops are growing in one-third of total cropland, while the total land area occupied by pasture is equivalent to $26 \%$ of the ice-free terrestrial surface [4]. In Central America there is a total area of 49 million hectares for agricultural and livestock use, of which 10 million are in pastures; approximately $20 \%$ of the soil in the region is devoted to activities related to livestock [5].

Livestock production continues to be dominated by conventional production systems, which are associated with low incomes for families, degradation of biodiversity and ecosystem services, increased vulnerability to climate change, and increased greenhouse gas emissions. The transformation of conventional livestock production into sustainable livestock production systems (this includes rational management of pastures food and nutrition, genetics and animal health, water management and integrated manure management), based on silvopastoral systems (SPS) and good livestock practices (GLP), contribute to improving livelihoods of families that base their economy in livestock activities [6]. Those families that practice SPS also improve the resilience of farms to climate change and the conservation of biodiversity [7]. Sustainable livestock system can contribute to the achievement of the Sustainable Development Goals (SDG) [8].

It has been demonstrated that livestock farms in the tropical regions managed under ecological principles, can contribute to the biodiversity because they can host a great diversity of tree species, whether they are natural regeneration, remnants of forest or plantation of species with timber potential [9]. Some of the main reasons why farmers remain motivated to conserve or plant trees on the farm id because of the provision of goods like firewood, timber, forage, shade, and food, and perhaps for their environmental services such as soil formation, conservation of water resources, connectivity, or carbon supply [10, 11, 12].

Knowledge of tree cover, species composition, and level of technological innovation in the different farms studied could help in the development of the sustainable livestock production systems within the framework of the national sustainable livestock strategy. In this research, we characterize livestock farms and the floristic composition of tree cover in the southeast region of Guatemala. Results are available to scientists, farmers, private and government institutions that oversee decision making to reduce vulnerability (drought and desertification) and increase the environmental and economic benefits of livestock activity.

\section{Material and Methods}

\subsection{Study Site}

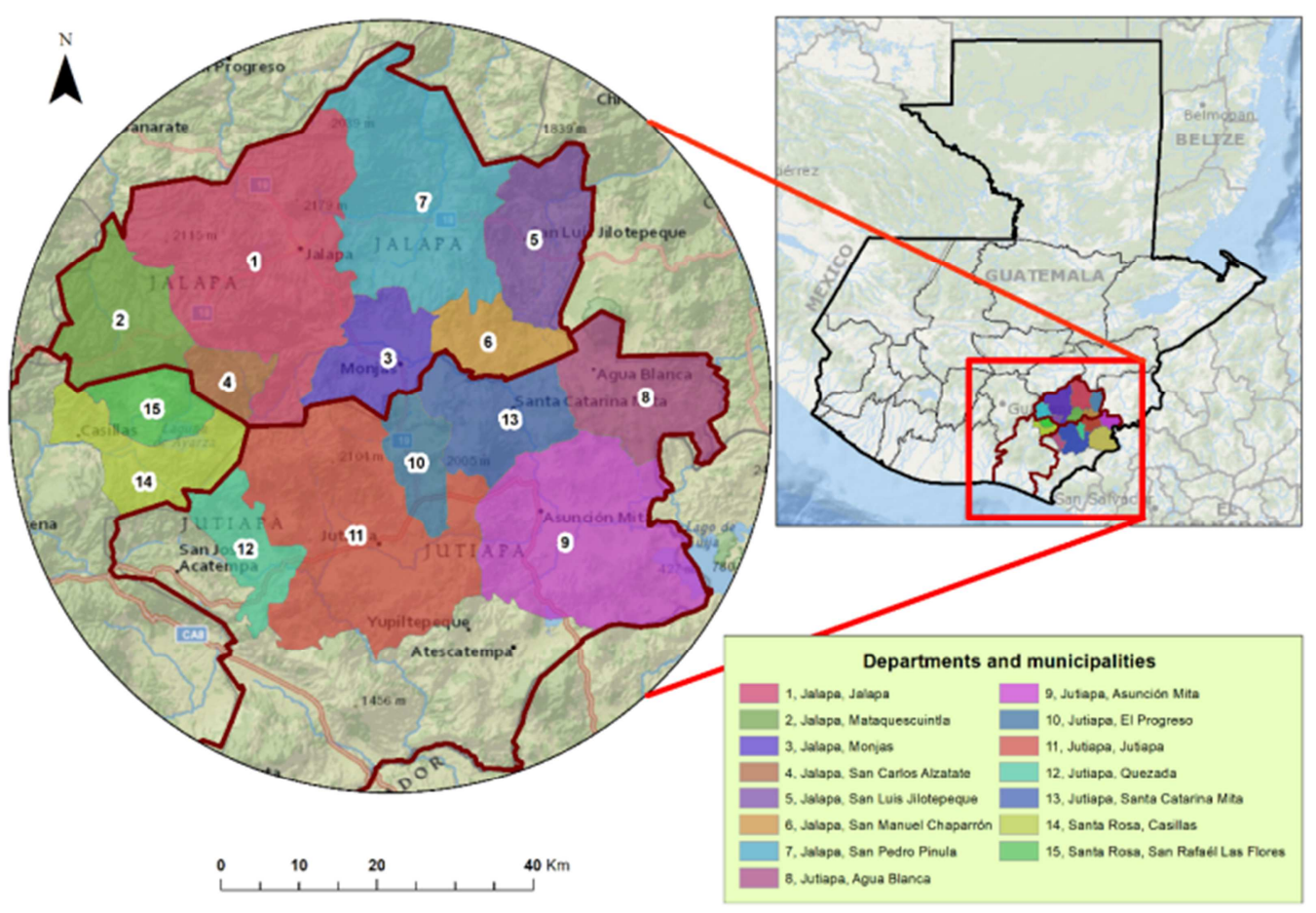

Elaborated by Ney Rios

Figure 1. Study area in the southeast region of Guatemala. 
The study was developed in three departments from the southeast region of Guatemala (Figure 1): Jalapa located at latitude $14^{\circ} 38^{\prime} 02^{\prime \prime}$ and longitude $89^{\circ} 58^{\prime} 52^{\prime \prime}$ with a territorial extension of $2,063 \mathrm{~km}^{2}$, Jutiapa located at latitude $14^{\circ} 16^{\prime} 58^{\prime \prime}$ and longitude $89^{\circ} 53^{\prime} 33^{\prime \prime}$ with a territorial extension of 3,219 $\mathrm{km}^{2}$, and Santa Rosa located at latitude 14'16'42"and longitude $90^{\circ} 18^{\prime} 00^{\prime \prime}$ with a territorial extension of 2,295 $\mathrm{Km}^{2}$. It covers the basin of the Lagoon of Ayarza (3,112.5 ha) and the upper and middle parts of the Ostúa River basin $(30,729$ ha and 52,239 ha, respectively). This region presented altitude ranges from 463 to 2039 meter above sea level (from now m.a.s.l). The variable of precipitation presented ranges from 822 to 1631 millimeters (from now on $\mathrm{mm}$ ) annual rainfall, temperature ranges go from 17.1 to $25.4^{\circ} \mathrm{C}$ (Celsius). This region includes two of the departments with the highest threat of desertification in the country (Jalapa and Jutiapa) and a greater susceptibility to drought. Loss of forest cover is mainly due to the advance of the agricultural frontier, livestock activity, deforestation of forests for firewood and wood extraction, forest fires, and to a lesser extent, the demand for land for urbanization and housing construction in the rural area [13].

\subsection{Farm Selection}

There were a selection of 60 farms based on the following general criteria: 1) the main economic activity is cattle raising, 2) the family owns the farm, 3) farmer willingness to cooperate in the study, 4) the farm represents one of the typologies of environmental livestock present in the area, 5) there is forest cover, scattered trees or other tree presence on the farm, 6) the property is not on sale and the family has long-term plans for the livestock activity, and 7) there are good animal husbandry practices such as genetic improvement, improved nutrition and animal welfare. Those farms selected were part of the data base of the project "Sistemas de producción ganaderos climáticamente inteligentes basados en sistemas silvopastoriles en 15 municipios del suroriente de Guatemala" executed in the years 2016-2018. Out of the sample of 60 farms, there was a second selection of 30 farms based on 16 criteria's that involves the level of technological innovation. A score was given for each criterion these were the base to identify which farms were in high level of technological innovation and which ones were in low level of technological innovation. A semi structured interview was applied to the 30 farms to obtain the biophysical, socioeconomical and productive information of each farm.

\subsection{Tree Inventory in the Different Land Use}

Tree cover information was collected from trees scattered in paddocks, living fences, forest plantations, among others, following the protocol [14]. In each farm, in conjunction with the owner and using a map of Google Earth, a review and delimitation of the perimeters of the farm, the land use, and length of living fences were estimated. Each farm's localization was registered with the Global Positioning System (GPS) also the coordinates of the different measurement plots. All trees with a Diameter at Breast Height (DBH) greater than $5 \mathrm{~cm}$ were recorded.

The uses of land and living fences were verified and evaluated if they were homogeneous or heterogeneous (by topography, species, density of cover and management). The size of the plot to sample the tree cover was $1000 \mathrm{~m}^{2}(0.1$ ha). For land uses "trees scattered in paddocks" and "forests" these plots were established in a circular manner using a radius of $18 \mathrm{~m}$. In forest plantations, rectangular plots were used $20 \times 50 \mathrm{~m}$. The plots were distributed randomly. In living fences, the segment for sampling was $25 \mathrm{~m}$ with one meter on each side of the fence, and the location was at the midpoint of the live fence. The intensity of sampling varied between $1-5 \%$ depending on the size of the stratum (Table 2). The criterion defined was that in greater area used, the lower the sampling intensity [14].

Table 1. Level of sampling intensity by stratum size in land use of 30 livestock farms located in the southeast region of Guatemala.

\begin{tabular}{ll}
\hline Stratum area in land use (ha) & Intensity of sampling (\%) \\
\hline$<10$ & 5 \\
$10-20$ & 4 \\
$21-50$ & 3 \\
$>50$ & 1 \\
\hline
\end{tabular}

In each one of the tree plots, the information collected was common and scientific name of the tree, the DBH was measured at $1.30 \mathrm{~m}$ using a diametric tape and expressed in centimeters. When several axes were presented, each stem was measured independently, and the Mean Square Diameter was calculated per individual [15]. following the formula:

$$
\mathrm{MSD}=\sqrt{\Sigma} \mathrm{DBH} / \mathrm{n}^{2}
$$

Were:

MSD: Mean Square Diameter

$\mathrm{DBH}$ : addition of Diameter at Breast Hight divided into the number of axes

$\mathrm{n}^{2:}$ number of axes elevated to two

Total hight and commercial height were measured whit the use of a Clinometer Suunto. Crown cover, defined as the paddock our other land use percentage that was directly under crowns of individuals trees, these was measured from the reading of two perpendicular measurements covering the longest axes of the crown using a measuring tape of $50 \mathrm{~m}$. Sanitary state of the tree were evaluated by observation (healthy, sick, dead).

Information was collected with the help of Open Data Kitt (Is a set of tools that allow to collect data through mobile devices and send data to an online server even if there is no internet connection or access to a mobile network at the time of data collection) using a smart phone, this tool is important because it helps decrease the error in annotation it also permit the restriction of data that does not coincide with the information of the area where the study is carried out.

Data of the total head of cattle and category of each one 
was collected through the socioeconomical survey. This helps calculate the total animal unit and stocking rate in each department of the study using the following formula [16], [17].

\subsection{Calculating the Percentage of Tree Cover}

Tree crown cover was estimated in each one of the different land uses. The area $\left(\mathrm{m}^{2}\right)$ of the tree cover was obtained by measuring the perpendicular diameters of the area occupied by the tree canopy presented in each plot. The calculation of the tree canopy was done using the following formula:

$$
\mathrm{AC}:\left(\pi * \mathrm{R}^{\left.1 * \mathrm{R}^{2}\right) / 4}\right.
$$

Were:

AC: Area of crown

$\mathrm{R}^{1}$ : Radius of crown axis 1

$\mathrm{R}^{2}$ : Radius of crown axis 2

П: 3,1416

In order to obtain the percentage of tree crown cover for each land use, there was a summation of all AC and after a division between the area of the plot and multiplied by 100 , this result was used to calculate the average percentage of tree cover according to the number of plots by land use. This coverage was estimated for all timber and non-timber species following the formula:

$$
\mathrm{CC} \%=\left(\sum \mathrm{AC} / \mathrm{Ap}\right) * 100
$$

Were:

$\mathrm{CC}$ : Crown cover (in percentage)

$\sum A C$ : Summation of crown area $\left(\mathrm{m}^{2}\right)$ of all tree species
Ap: Area of the plot were sample was taken $\left(\mathrm{m}^{2}\right)$ $100=$ Conversion factor in $\%$

\subsection{Data Analysis}

Infostat (software that covers all the basic needs for descriptive statistical analysis and the production of graphics for the exploratory analysis) [18] was used to make conglomerate analysis (dendrogram of the typologies of livestock farms), bar graphics of tree cover percentage and classification of diametrical class of all tree. Q-eco (statistical software for analysis of ecological data) was used applying community- diversity- diversity index. Also, communityordinations-unconstrained-nonmetric multidimensional scaling of all tree species [19]. This allowed the calculation of:

Rényi $\mathrm{Hi}=\ln (N q)$, where Nq corresponds to the values of the series of Hill numbers, in a profile of the series of Hill numbers, this expresses that one site is more diverse with respect to another site if the diversity profile is maintained above in parallel. Hill series of numbers measures the effective number of species in a sample, when each species is weighted by its relative abundance.

\section{Results}

\subsection{Livestock Farms and Its Typologies in the Region}

Farmers in this region owned his farm for a long time. These lands usually are inherited, and it makes the distribution of the farms by size very heterogeneous. The production unit is usually composed of a single farm, but it is common to find fractionation of the production unit in different localities at different gradients in the agricultural landscape.

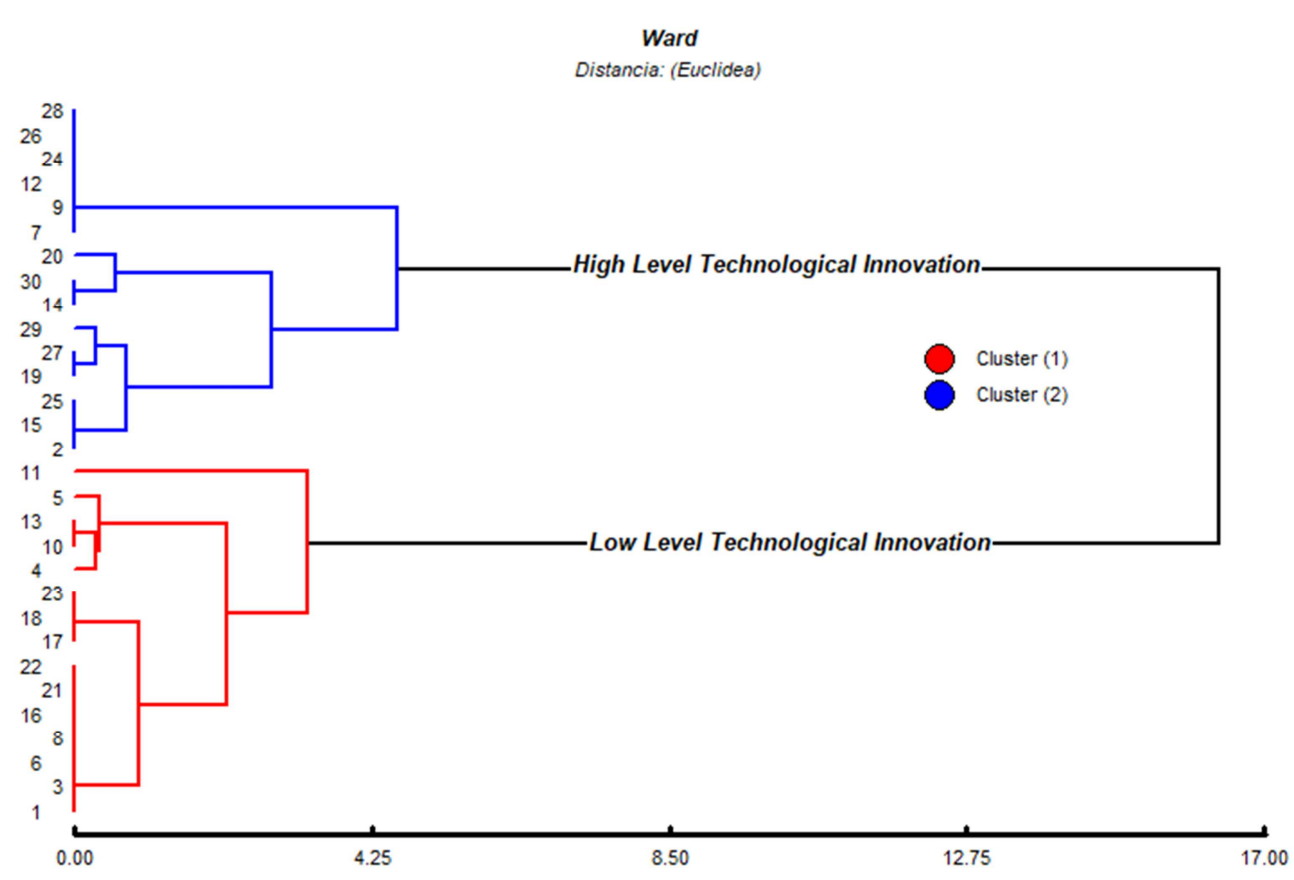

Figure 2. Dendrogram of classification according to technological level of innovation of 30 livestock farms located in the southeast region of Guatemala.

Workforce is mainly family members; however, in many of the cases there are permanent employees who work on the 
farm. Out of the thirty-survey conducted, $97 \%$ of farmers were male and $3 \%$ female. Livestock farms in the southeast region presented family size of $5 \pm 1.68$ individuals, farmer's age presented an average of $47 \pm 12 \mathrm{yrs}$, and academic level had an average of $9 \pm 5.55$ yrs among all farmers in the three departments. Farm size presented an average of $26.33 \pm 22.4$ ha, with stocking rate of $3.39 \pm 3.35 \mathrm{AU} / \mathrm{ha}$. In addition to the livestock component, farms have agricultural activities, forestry, and agroforestry systems. The proportion of land use reflects the tradition of livestock as an economic activity in this region for many years.

In the southeast region of Guatemala, there were identified two typologies of farms (Figure 2): those with high level of technological innovation (HLTI) and farms with low level of technological innovation (LLTI). Farms with HLTI had total land average of $26.93 \pm 20.91 \mathrm{ha}$; the area dedicated to livestock activity had an average of $14.96 \pm 11.03$ ha. This group presented stoking rate of $6.09 \pm 4.81 \mathrm{AU} / \mathrm{ha}$. Herd's size had an average of $56.80 \pm 32.70$ animal unit, with average of milk production of $5125.2 \mathrm{l} / \mathrm{ha} / \mathrm{yr}$. Age of farmers presented an average of $45 \mathrm{yrs}$, and the average of education level were 10.6 yrs. It was found that farms in this group presented $14 \%$ of natural forest.

These are known for the implementation of silvopastoral systems and sustainable practices and livestock activity is based on specialized dairy system in $66.6 \%$ and double purpose in $33.3 \%$.

Farms with LLTI had a total land average of $25.74 \pm 24.56$ ha, in average land dedicated to livestock activity was 19.68 $\pm 20.59 \mathrm{ha}$, and they presented stocking rate of $4.41 \pm 3.93$ AU/ha. Herd's size had an average of $60.5 \pm 72.04$ animal unit, with average of milk production of $2071.1 \mathrm{l} / \mathrm{ha} / \mathrm{yr}$. Age of farmers presented an average of $49 \mathrm{yrs}$; the average of education level were 7.77 yrs. Farms in this group presented $9.6 \%$ of natural forest.
These farms are known for the low implementation of silvopastoral system and sustainable practices on the farm; livestock activity is based on double purpose in $60 \%$, specialized dairy are present in $33.3 \%$ and cattle fattening in $6.6 \%$.

\subsection{Floristic Composition, Richness and Structure of Tree Cover}

Before getting in context is important to manage the following definition:

Agrosilvicultural systems (ASS): They are a combination of crops and trees, such as alley cropping or home-gardens.

Fodder banks (FB): It is an enclosed area of concentrated forage legumes reserved for dry season supplementary grazing.

Forest plantation (FP): It is a project that is established with the main objective of producing sawmill wood or raw material to supply the forestry industry.

Living fences (LF): They are trees that are mainly related to the delimitation of farms and pastures; it may be made up of only woody species only or a combination of woody species with dead poles.

Natural forest (F): It is the ecosystem where trees are the dominant and permanent plant species, they are originated by natural regeneration without influence of human beings.

Riparian forest (RF): It refers to the arboreal and shrub vegetation located in the margins of rivers, streams, and other bodies of water.

Scattered trees in paddocks (STP): These are trees that can be originated from natural regeneration or by plantations; the presence of trees depends on the availability of seed sources in or near pastures where regeneration is controlled by environmental factors, (water, light, and nutrients), type, and mobility of dispersing agents.

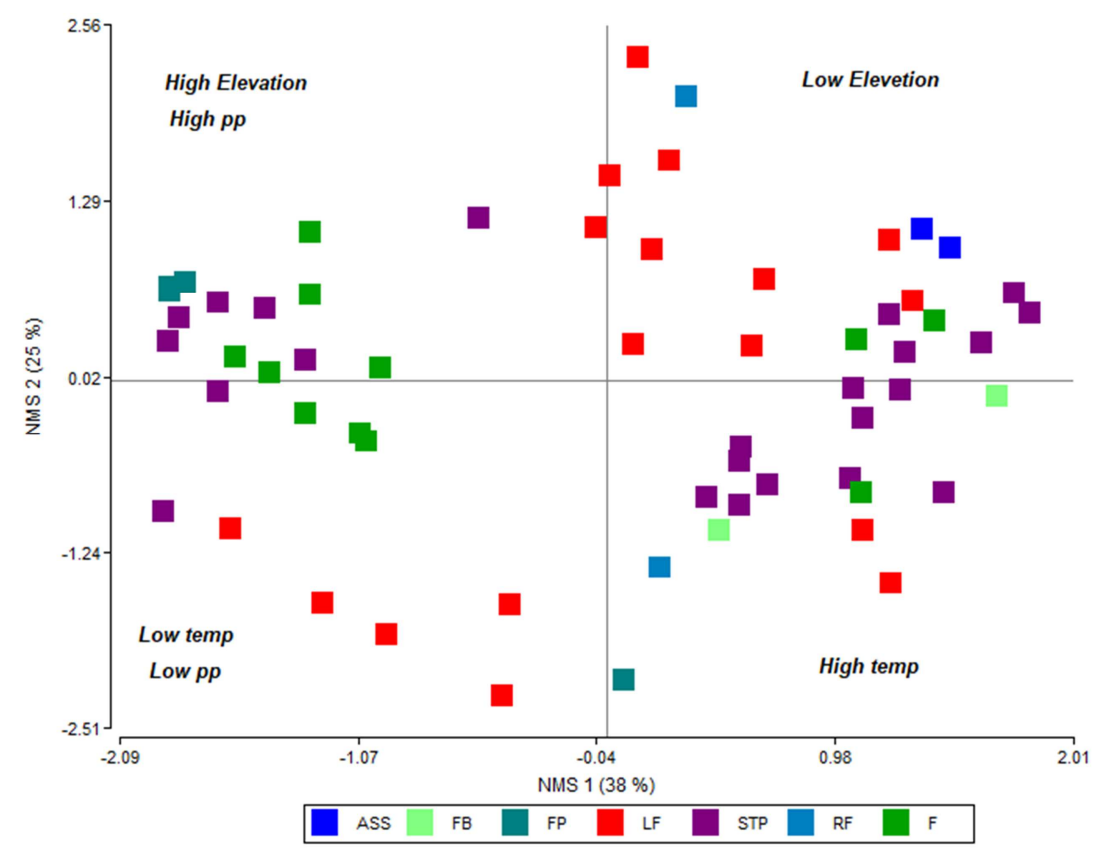

Figure 3. Tree distribution in relation whit elevation, temperature and precipitation of 30 livestock farms located in the southeast region of Guatemala. 
There are two remarked gradients of tree distribution based on elevation, temperature, and precipitation (pp) (Figure 2). Trees in high elevation are related to high $\mathrm{pp}$ and low temperature; and trees in low elevation are related to low $\mathrm{pp}$ and high temperature. This figure explains $63 \%$ of the floristic composition inside the livestock farms systems studied in the southeast region of Guatemala. In areas with high elevation, the land use with more density of trees was F, followed by STP, LF, and FP. In areas with low altitude, STP dominates much of the land use, followed by LF, F, ASS, FB, RF, and FP.

In the study area there was a total of 4,678 trees $(\mathrm{dhb}>5$ $\mathrm{cm}$ ), from thirty-seven families and eighty-three species in an area of 790 ha out of which 169.1 ha presented LF. When analyzing the phytosanitary state of trees, it was found that $98 \%$ were in a healthy condition, $1.2 \%$ were identified as sick (fungus disease), and $0.8 \%$ were dead. This reflects that livestock landscape plays an important role in the conservation of tree diversity. The most abundant class of timber present in the study area was Pinus spp and Quercus spp, the most abundant non-timber species found was Gliricidia sepium and Acacia pennatula.

When the composition and abundance of species and individuals by land use were compared, it was found that ASS presented a total of sixty-two individuals that belong to seven species and six family, out of which the three most abundant conforms $90.2 \%$. Gliricidia sepium was the most abundant specie. FB presented a total of thirty-six individuals that belong to six species and two families, the three most abundant conforms $91.5 \%$. Acacia pennatula was the most abundant specie.

FP presented a total of 413 individuals that belong to seven species and six families, out of which the three most abundant conforms $96.8 \%$. Pinus spp held the highest percent in this group because of farmers preference (quality wood and resin) and the adaptability of adaptation of this species in the region. LF presented a total of 635 individuals in a total area of $1.691 \mathrm{~km}$, these individuals belong to forty-six species and twenty-two families, out of which the three most abundant conforms $43.5 \%$. Tabernaemontana donnell-smithii was the species that presented the largest number of individuals with $19.4 \%$.

STP presented a total of 1,537 individuals that belong to fifty-one species and twenty-four families, out of which the three most abundant conforms the $52.7 \%$. Gliricidia sepium was the species that represent the largest number of individuals with $22.3 \%$. RF presented a total of sixty-six individuals that belong to nine species and six families, out of which the three most abundant conforms $80.1 \%$ Inga edulis was the most abundant species. F presented a total of 1,929 individuals that belong to fifty species and thirty families, out of which the three most abundant conforms 70.4\%. Quercus spp. was the most abundant species in this land use.

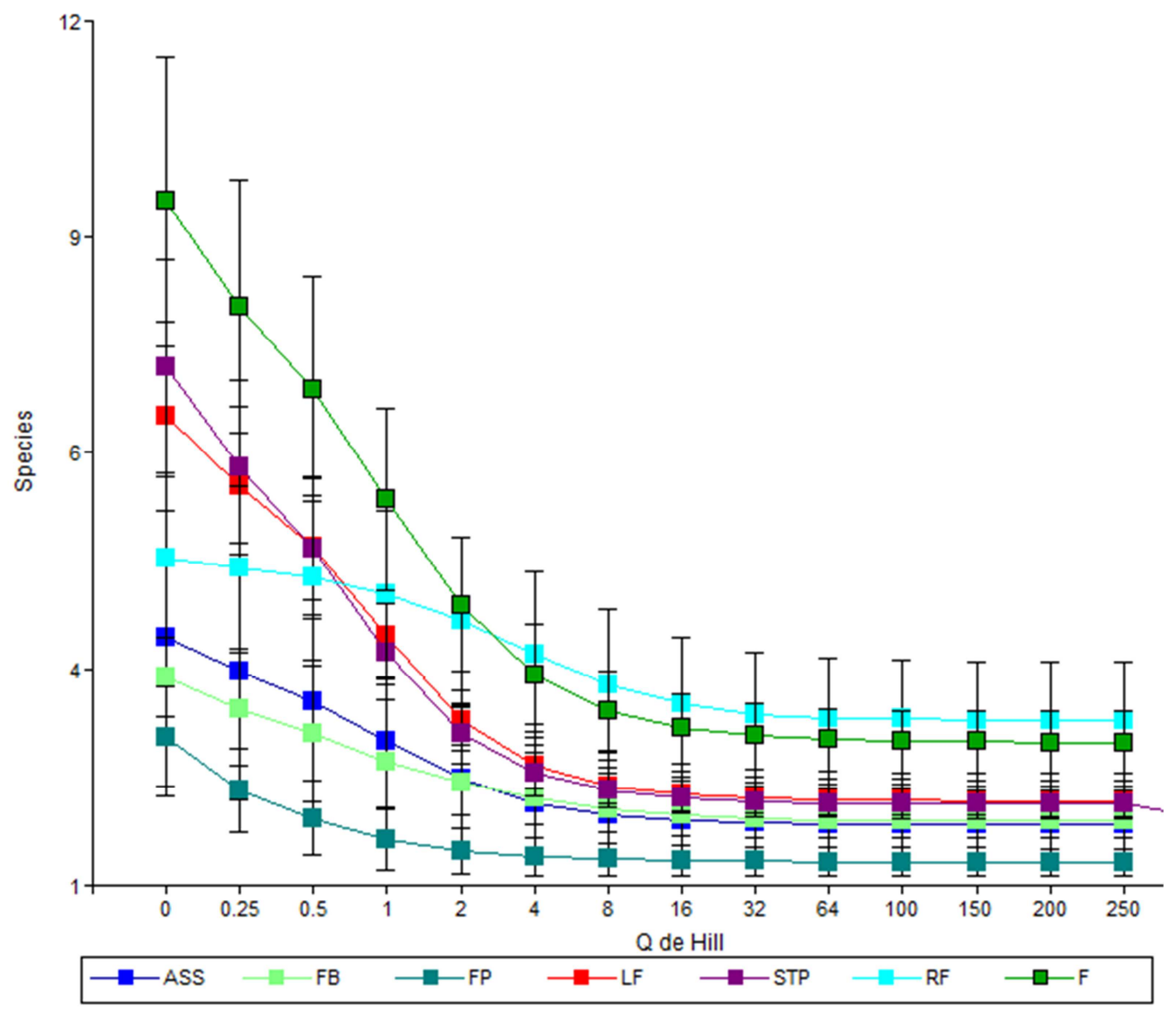

Figure 4. Tree species distribution in the southeast region of Guatemala using Index of Rényi (Q-Hill). 
Table 2. Three most common tree species found in each land use in the thirty livestock farms evaluated in the southeast region of Guatemala in descending order of abundance.

\begin{tabular}{llllll}
\hline Species & Abundance (\%) & Species & Abundance (\%) & Species & Abundance (\%) \\
\hline ASS & & FB & & FP \\
Gliricidia sepium & 61.2 & Acacia pennatula & 61 & Pinus spp & 89.5 \\
Inga jinicuil & 16.1 & Crescentia alata & 19.4 & Pachira aquatica & 4.6 \\
Yucca gigantea & 12.9 & Gliricidia sepium & 11.1 & Eucalyptus spp. & 2.7 \\
n. Ind & 62 & & 36 & 413 \\
LF & & STP & RF & Inga edulis \\
Tabernaemontana donnell-smithii & 19.4 & Gliricidia sepium & 22.3 & Acacia pennatula & 22.7 \\
Jatropha curcas & 15.9 & Acacia pennatula & 16.9 & Caesalpinia velutina & 19.6 \\
Bursera simaruba & 8.18 & Pinus spp & 13.5 & & 66 \\
n. Ind & 635 & & 1537 & & \\
F & & & & \\
Quercus spp. & 43.2 & & & \\
Pinus spp & 23.3 & & & \\
Tabernaemontana donnell-smithii & 3.9 & & & \\
n. Ind & 1929 & & & \\
\hline
\end{tabular}

According to Q-Hill (Figure 4) there are few species with high abundance and a significant group of species are only represented by few individuals. The ten most abundant species found in the study constitutes $77.27 \%(3,215$ individuals). Trees inside of F, STP, and LF have a high number of species and individuals inside the plant's community. Land use with RF, ASS, FB, and FP apparently have an equitable distribution of tree species and few individuals through the land use. There were marked differences of richness by individuals and density of species accumulated by land use.

It was found that species inside of ASS presented low diameter class and few individuals (Figure 5.a and 5.b); it can be due to the selection made by the farmer and the purpose of these in the system. FB presented a high number of species and individuals in diametrical class 10 and $20 \mathrm{~cm}$. In FP there is a significant group of individuals with diameter between 10 and $20 \mathrm{~cm}$ and few species were found in the diametrical class from 30 and $40 \mathrm{~cm}$.
LF presented a high number of species and individuals in diameter class between 5 and $10 \mathrm{~cm}$. In this land use there were few species recorded with diameter greater than $>50$ $\mathrm{cm}$. STP presented a great number of species with diameter between 10 and $20 \mathrm{~cm}$, and a high number of individuals in diameter class 5 and $10 \mathrm{~cm}$. Trees in this land use presented approximately thirteen species and 100 individuals in the diameter class 30 and $40 \mathrm{~cm}$. There were also species with few individuals above $>50 \mathrm{~cm}$ diameter class.

RF presented approximately seven species between diametrical class from 5 and $10 \mathrm{~cm}$; however, there was a very low number of individuals in comparison with the rest of land use in the different sites where the study was carried out. F was the land use with the greatest number of species with diameter class between 5 and $10 \mathrm{~cm}$. It also presented the highest number of individuals between the diameter class 10 and $20 \mathrm{~cm}$. Data presented in this study is the accumulation of species and individuals founded in each land use.

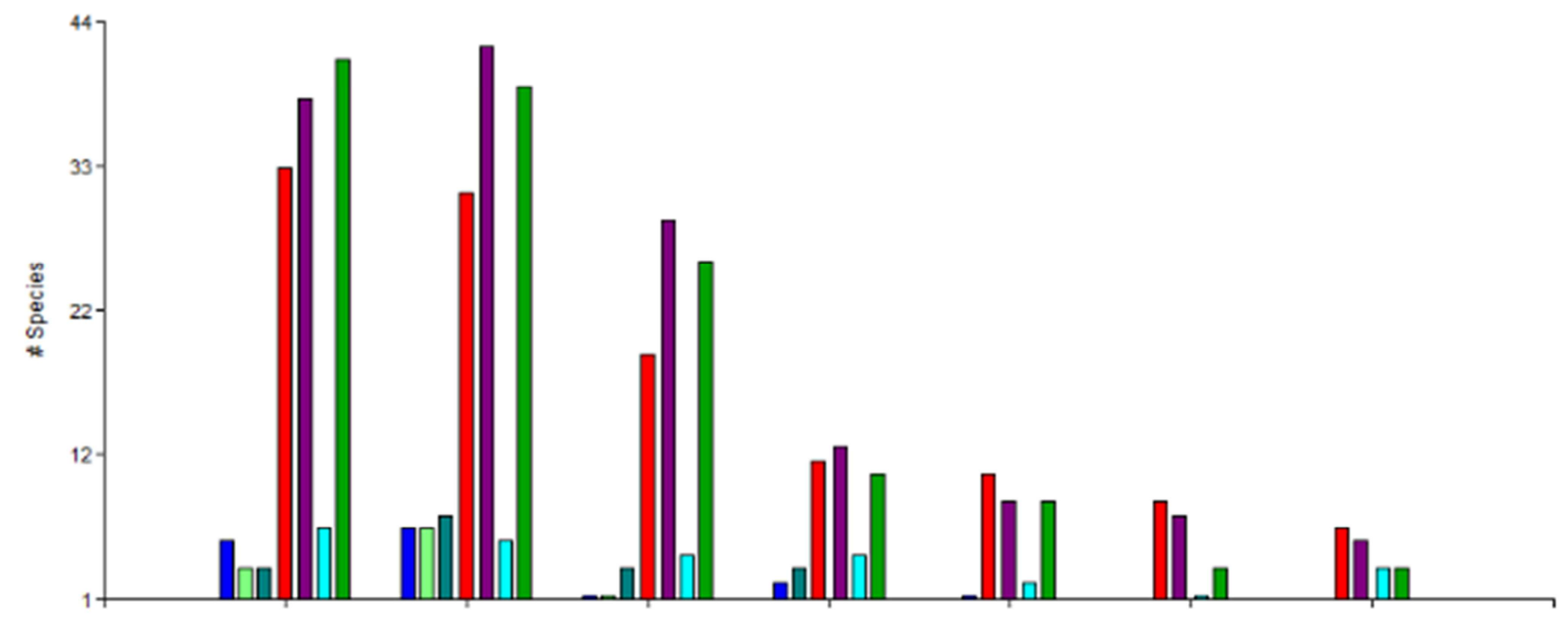




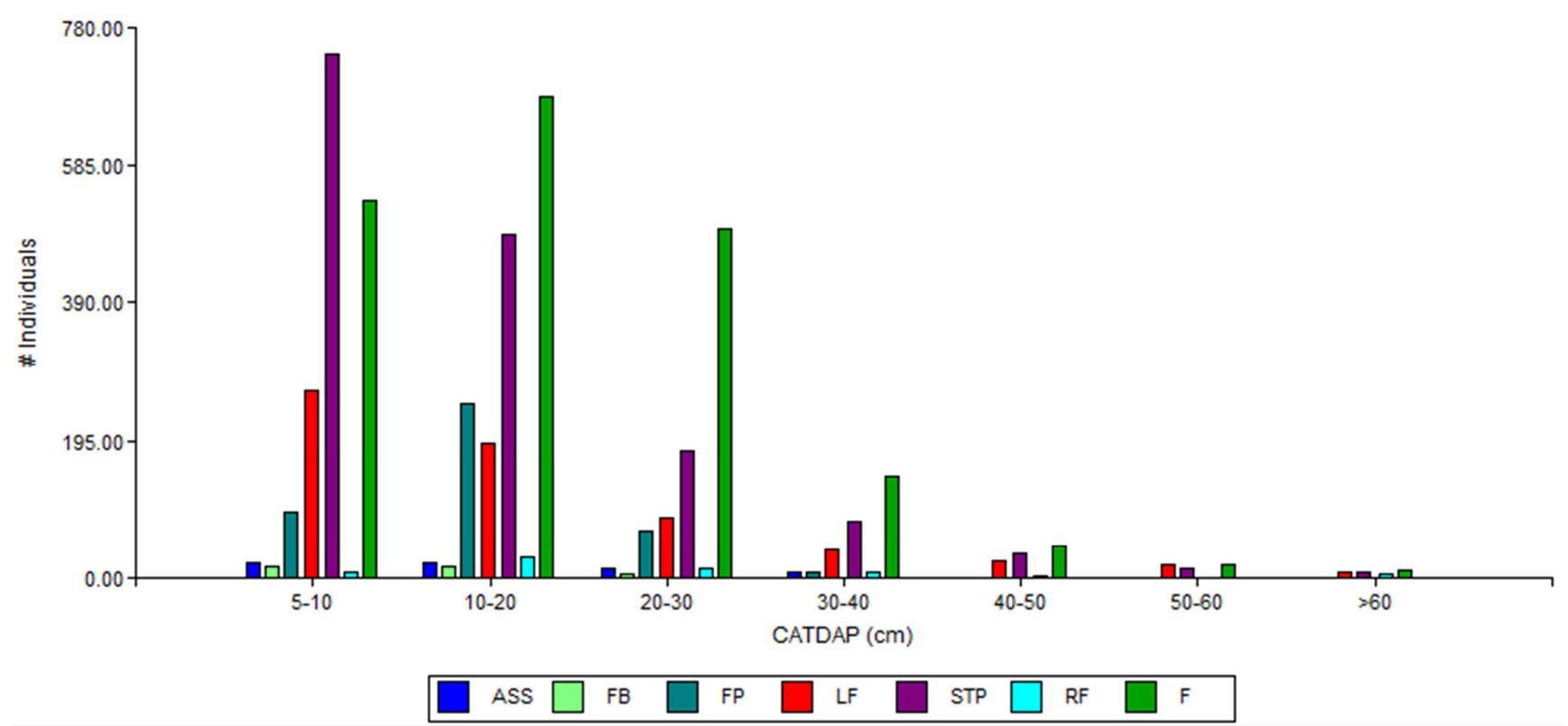

Figure 5. Diametrical class for 30 livestock farms located in the southeast region of Guatemala.

a) Number of species in each land use and diametrical class.

b) Number of individuals in each land use and diametrical class.

\subsection{Percentage of Tree Cover Inside the Different Land Use}

Farms with HLTI presented an average of $31.2 \%$ of tree cover in $\mathrm{F}$ and $23.4 \%$ of tree cover in STP. Farms with LLTI presented inside of F $26.8 \%$ of tree cover and $28.9 \%$ of tree cover in STP. In both level of technological innovation ASS, FB and RF had low percentage of tree cover inside the system (Figure 6). It is important to highlight that farms with HLTI presented a higher percentage of tree cover within their livestock system, compared with does that had LLTI.

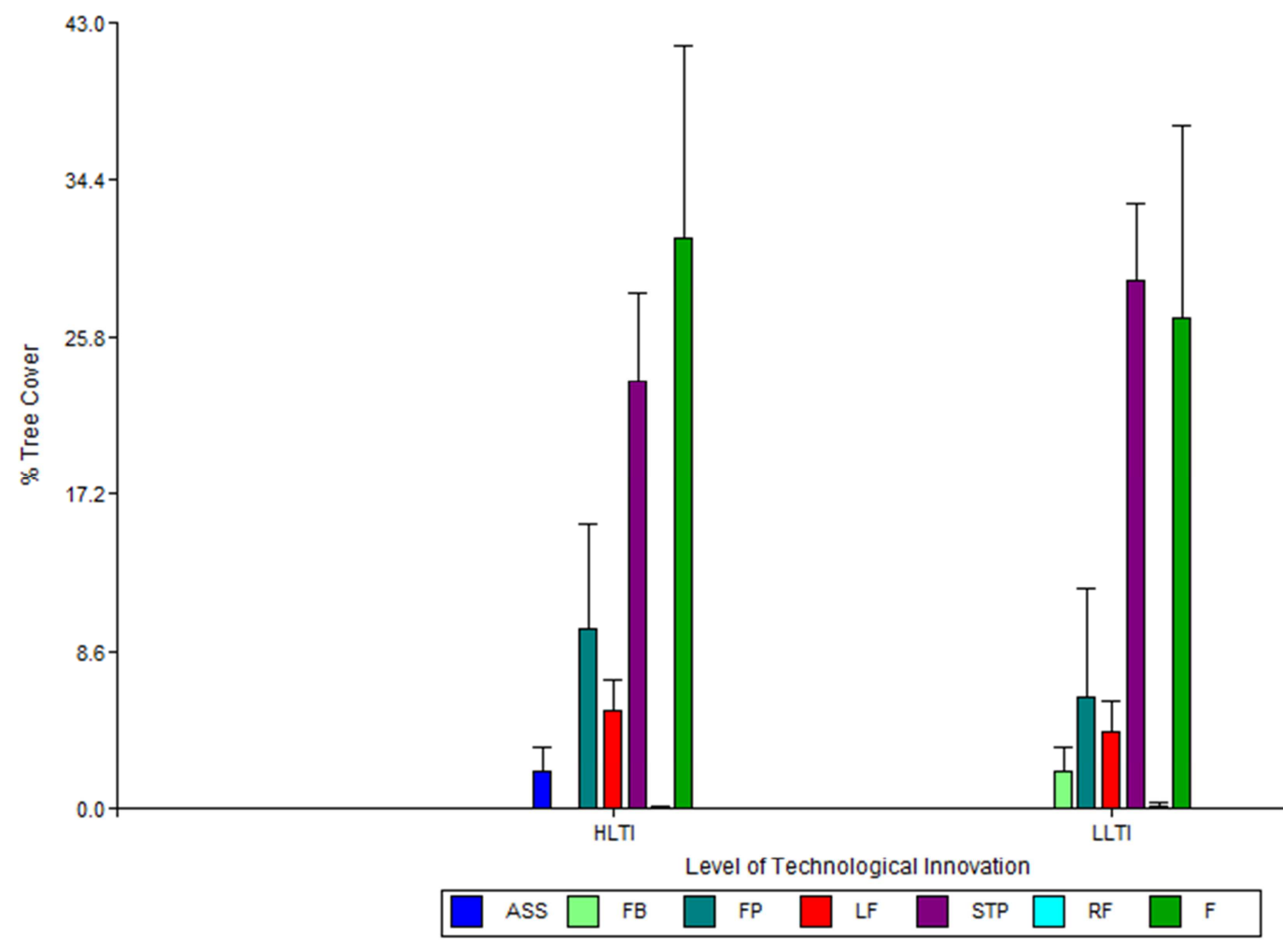

Figure 6. Percentage of tree cover by level of technological innovation in the different land use. 


\section{Discussion}

Study showed that farms in the region follows the national patterns in size and stocking rate. I was also found that farmers with low level of education has higher probability to belong to the group with low level of technological innovation; meanwhile farmer with more yrs of education tend to belong to the group with high innovation, and had better access to training. Farmers with large areas tend to adopt more innovation than those with small areas, these can be probably because producers with big farms has more capacity of investment and they work with economies of scale [20].

Famers in the study area are capable of identifying tree species present on their farms also the ecological an economical value of these. Farmers in this region managed species like Gliricidia sepium because of the provision of shade and organic matter, provided by the leaf to the soil which benefits coffee plants, it also provide forage and timber products (post and firewood mainly). In a recent study in Costa Rica it was found that the level of water infiltration in a coffee agroforestry system was greater than in a coffee monoculture [21]. Tree roots swell, shrink, die and decompose, all of which promote macropore formation and trees also add organic matter to the soil via pruning and deposition of residues in the soil, and root turnover [22]. This coincide with the statement of farmers that manages agroforestry systems in the southeast region of Guatemala. Farmers use Acacia pennatula that is characterized by its open branches that not only allow the penetration of sunlight and present low competition for the main crop, but also give fruits that are used for cattle feeding during the dry season. This is considered a multifunctional specie because it also gives firewood and dead post for fences. Tree shade reduces light penetration to understory crops, limiting their rate of photosynthesis [23]. While crop yield penalties are expected because of tree - crop competition for resources, farmers still maintain trees on their farms. On-farm trees are also maintained for their social and cultural values [24]. Nevertheless, in agroforestry systems applying good practices such as the reduction of tree density and good arrangement trough pruning can help improve the positive interaction between crops/grasses and trees. In the study area there were few farmers with forest plantation although they are economic incentive by PINPEP (Forest Incentives Program for Small Farm owners with Forest or Agroforestry Land) and PROBOSQUE (another Incentives Program of the National Forest Policy), that give economic incentives, to the owner of forest land, for carrying out reforestation or natural forest management projects [25]. Both programs are working towards the mitigation of climate change and conservation of biodiversity in the region. In a research carried out in Guatemala it was found that annually, the number of PINFOR (now PROBOSQUE) users increases, instrument with which the population had benefited socially Guatemalan rural area, where the State has invested Q918 million (equivalent to US \$ 122.4 million), which has generated 203,783 jobs and benefited 2.6 million people [26], [27].
Farm forestry could potentially provide: carbon credits, based on carbon sequestered by plantations; salinity credits, based on the positive impact of plantations on dryland and irrigation salinity; water filtration credits, based on farm forestry reducing salt, excess nutrients and turbidity in our waterways; and biodiversity credits, where farm forestry activities maintain and restore a region's natural flora and fauna [28]. Farmers can increase their potential of livestock farms (sustainable intensification of cattle farms) by inserting some areas with forest plantations and releasing areas not suitable for agricultural production, to give way to the natural regeneration of secondary [29]. There were species like Tabernaemontana donnell-smithii that were presented in live fences demonstrating that this areas on the farms can be used for the establishment of trees that have high commercial value and can adapt easily to the climate condition also present rapid growth inside of their live fence. The productive role of this live fences on the farms were to divide pastures and serves as barrier to animal movement. Similar results were found where live fences was used as a source of fodder, firewood, timber and fruit [30]. Farmers in the southeast region of Guatemala retain some species of tree in their paddocks because of their value in the provision of shade, fruits or foliage that can be eaten by the cattle, or because these are important firewood or timber species that family can make use of. Tree are retained because of their value as shade, fodder, timber, firewood and post for division inside of the farms [31], [32]. Species like Inga edulis are retained by the farmers due to the role they play in maintain the water springs, that is used for the different activities on the farm specially for the livestock production. Riparian forests prevent freshwater pollution and they represent one of the most valuable management tools for preventing excess nutrient loss from land to water [33]. Farmer with natural forest sustain that they receive benefits such as wood, poles, firewood and shade for the cattle during days with high temperature. In a research it was also found that farmers manage the tree cover to provide shade, forage to livestock, and obtain products such as fruits, timber, firewood and poles [34]. Just $6 \%$ of farmers received economic compensation by PINFOR for maintaining the forest land and few express the benefits of $\mathrm{F}$ for the biodiversity in their productive system. In the seven different land use studied, it is clearly demonstrated that tree cover inside livestock production systems are important because of the positive relation of these with the provision of goods to the family and the capacity of carbon sequestration, generated by the activity. It also gives a high value to the property and make farmers more resilient to the effects of climate change because of the provision of wood and non-wood products, that they receive throughout the year. Many agricultural landscapes, despite being highly fragmented and deforested, still retain abundant on-farm tree cover in the form of small forest patches, living fences, forest fallows and isolated trees [35]. In a research is was found that forest patches, isolated trees, and windbreaks are important for conserving both local and regional biodiversity because they provide important food sources, 
nesting sites, and habitats for a variety of animal species (particularly birds) and may serve as stepping stones or corridors that facilitate animal movement across the agricultural landscape. They also help conserve plant diversity, trees themselves often represent forest species that would otherwise be absent from the landscape and because trees serves as host for numerous epiphytic plants [36]. Diversity and greater structure of the arboreal coverage from the wooded paddocks and forest, gathers a series of functional traits with potential for the development of sustainable livestock production system with positive effects at both farm and landscape levels. At the productive and socioeconomic level, trees in pastures and live fences can diversify and increase the economic income of the families through products such as wood, poles, firewood, seeds, forage, fruits and other goods and services with potential to be commercialized or used on the farm [37]. Its suggested that living fences offer an opportunity to increase habitat availability and maintain some degree of landscape connectivity in agricultural landscapes [38]. The existent patterns of on-farm tree cover reflect farmer decisions to plant, retain or remove trees on their farms according to their productive interest at the moment. In a study it was demonstrated that large tree seedling damage can be caused by cattle trampling, defoliation, and damage of young trees occurred in paddocks managed in a very intensively manner (high stoking rates and heavy grazing regimens) than those paddocks less intensively managed [39]. In a research it was found that a small number of individuals in the lowest DBH category $(10$ to $20 \mathrm{~cm})$ indicated a low rate of natural regeneration, which may be associate with grass species sown and paddocks management practice, particularly weed control [40]. Making a synthetic analysis it is evident that the majority of species and individuals are found in low diameter class, which represents a high tendency of some species to become extinct in the region because of the absence of seed and seedling for the natural regeneration and the establishment of a forest plantation. These can be species of high commercial value or species with an important value for biodiversity inside of the dry corridor region. It is important to promote silvicultural management inside of the different land use. This can help decrease the pressure on tree coverage in each farm, contributing to the selection and retention of mother trees as a source to obtain seed and seedling with desirable characteristics.

To improve the composition and structure of tree cover in Guatemala, regarding legislative matters, the forest law of 1996 is still in place and it provides framework in legal matters for Sustainable Forest Management (SFM). The law established that $80 \%$ of the yearly amount of PINFOR shall be allocated to plantations and the remaining funds could be destined for the managing of natural forest. The incentives are a cash payment that the government grants to the owner of forest, in order to enforce reforestation projects or managing of natural forest [41]. PROBOSQUE law established in article 2-2015 and it pursues five objectives, of which two are highlighted in this research: 1) Increase forest productivity through the establishment of forest plantations for industrial and energy purposes and the productive management of natural forests, decreasing the pressure on natural forests and other associated resources 2) promote forest diversification in land suitable for agriculture and livestock and the restoration of degraded forest lands, through agroforestry systems, forest plantations and other modalities that contribute to the provision of wood in rural areas and the recovery of the productive and protective base of degraded forest [42]. Establishment of pilot farms in the region, capacitation to technicians and farm owner are key points in the contribution to conserve and increase forest cover inside livestock system. These successful experiences demonstrate that it is possible to combine trees and animals in the same space and at the same time, creating a positive interaction while mitigating the effects of greenhouse gas emission into the environment.

The study showed that farms with HLTI presented a higher percentage of tree cover within their livestock system, this may due in part that these farms had less extension of land but devote more areas to keep trees (natural forest and forest plantation) for different reason and they manage specialized dairy system. Farms with LLTI had more extension of land but devote their activities to cattle production in dual purpose system which are still being practiced in a traditional manner (low number our absence of trees in paddocks). In active paddocks with Brachiaria brizantha in Esparza, Costa Rica it was found that the average of tree cover in dual purpose system varies between $16.4 \pm 1.8$ and in meat production system it varies between $17.8 \pm 2.1 \%$ [43]. In specialized milk system in Rivas, Nicaragua paddocks with high coverage presented an average of $24 \%$, in intermediate coverage an average of $8 \%$ and in low coverage an average of $4 \%$ [44]. Also, in Rivas, Nicaragua, it was found that shade of the trees reduces the caloric stress of the cattle, which is transformed in higher milk production between 1 and 3 lts/cow/day [45]. The design of a silvopastoral system should integrate deciduous and evergreen trees, since the cows use different groups throughout the year. In rainy season the protective effect of the deciduous and evergreen trees is the same, but despite this the cows prefer the deciduous trees [44]. It is important to consider diversity of trees to ensure shade throughout the year because some have leaves all over the year and others in certain months of the year, this diversity of trees also means to have a multifunctional silvopastoral system.

\section{Conclusion}

Tree cover is becoming very important for livestock farms in the southeast region of Guatemala, farmers conserve a significant number of tree species for different purposes. In the dry corridor this pilots farm can contribute to the process of adaptation and mitigation to climate change effect on livestock activity. Therefore, it is still necessary participatory research with farmers that explains in more details the positive contribution that tree provides in the different land 
use on livestock farms. The majority of species and individuals studied were found in low diametrical class, which represent a high tendency of some species to become extinct in the region because of the absence of seed and seedling for the natural regeneration and the establishment of a forest plantation. These can be species of high commercial value our species with an important value for biodiversity inside of the dry corridor region.

\section{Acknowledgements}

We thank the support and technical advice received from the project "Sistemas de producción ganaderos climáticamente inteligentes basados en sistemas silvopastoriles en 15 municipios del suroriente de Guatemala" executed in the years 2016-2018.

\section{References}

[1] FAO (Food and Agriculture Organization of the United Nations). 2016. Global forest resources assessment 2015: How are the world's forests changing. Segunda edición ed. Roma, Italia. Consulted 28. Mar. 2018. Retrieved from http://www.fao.org/3/a-i4808e.pdf

[2] Cherrington, E; Hernández, B; García, B; Oyuela, M; Clemente, A. 2011. Land cover change and deforestation in Central America 1990-2008. Ciudad Panamá, Panamá. Consulted 28. Mar. 2018. Retrieved from https://servirglobal.net/Portals/0/Documents/Articles/Regional \%20Assessment\%20Rpts/servir_deforestation_1990-2008.pdf

[3] Monterroso, O; López, G; Gálvez, J. 2012. Análisis sistémico de la deforestación en Guatemala y propuesta de políticas para revertirla. Ciudad Guatemala, Guatemala. (Serie técnica No.38). Consulted 28. Mar. 2018. Retrieved from https://www.url.edu.gt/publicacionesurl/FileCS.ashx?Id=4040 2

[4] FAO (Organización de las Naciones Unidas para la Agricultura y la Alimentación). 2018. El papel de la FAO en la producción animal (en línea). Roma, Italia. Consulted 20 May. 2018. Retrieved from http://www.fao.org/animal-production/es/

[5] Acosta, A; Valdés, A. 2013. Lineamiento de políticas: Situación y perspectivas del sector ganadero en Centroamérica. In Acosta, A; Díaz, T. (eds.). Lineamientos de política para el desarrollo sostenible del sector ganadero. Food and Agriculture Organization of the United Nations (FAO), Roma, Italia. p. 7-19.

[6] Casasola Coto, F; Villanueva Najarro, C. 2015. Buenas prácticas: para la mitigación al cambio climático de los sistemas de producción de leche en Costa Rica. $1^{\circ}$ ed. Turrialba, Costa Rica. 130 p.

[7] FAO (Food and Agriculture Organization of the United Nations). 2009. The state of food and agriculture. Livestock in the balance. Roma, Italia. Consulted 28. Mar. 2018. Retrieved from http://www.fao.org/docrep/012/i0680e/i0680e.pdf

[8] FAO (Food and Agriculture Organization of the United Nations).2015. Síntesis - Ganadería y los Objetivos de Desarrollo Sostenible. Roma, Italia. Consulted 5 of Feb. 2019. Retrieved from http://www.livestockdialogue.org/fileadmin/templates/res live stock/docs/2016/Panama/FAO-

AGAL_synthesis_Panama_Livestock_and_SDGs_SP.pdf

[9] Villanueva, C; Ibrahim, M; Harvey, C; Esquivel, H. 2003. Tipologías de fincas con ganadería bovina y cobertura arbórea en pasturas en el trópico seco de Costa Rica. Agroforestería en las Américas 10(39-40):9-16.

[10] Duffy Brittany, A. 2016. Trees in the Agricultural Matrix: Reforestation Processes in a Tropical Dry Landscape in Chinandega, Nicaragua. Tesis Máster. Florida, Estados Unidos de Norte América Florida International University. 95 p. Consulted 17 de mayo. 2018. Retrieved from http://10.25148/etd.FIDC000716

[11] Russo, R; Botero, R. 2014. Ganadería de sombra: ¿mito o realidad? Ambientico 245:4-8.

[12] Sánchez D; Villanueva, C; Rusch, GM; Ibrahim, M; DeClerck, F. 2013. Estado del Recurso Arbóreo en Fincas Ganaderas y su Contribución en la Sostenibilidad de la Producción en Rivas, Nicaragua. Turrialba, Costa Rica. $50 \mathrm{p}$.

[13] PNUD (Programa de las Naciones Unidas para el Desarrollo). 2014. Manejo sostenible de bosques y múltiples beneficios globales. Cuidad Guatemala, Guatemala. Consulted 12. Mar. 2018. Retrieved from http://www.gt.undp.org/content/dam/guatemala/docs/prodocs/ undp_gt_manejobosques.pdf

[14] Detlefsen, G; Marmillod, M; Scheelje, M; Ibrahim, M. 2012. Protocolo para la instalación de parcelas permanentes de medición de la producción maderable en sistemas agroforestales de Centroamérica. Turrialba, Costa Rica, CATIE. 36 p. (Serie Técnica. Manual Técnico no. 107).

[15] Snowdon Peter, RJ, Keith Heather, Ritson Peter, Grierson Pauline, Adams Mark, Montagu Kelvin, Bi Hui-quan, Burrows William, Eamus Derek 2002. Protocol for Sampling Tree and Stand Biomass. Australia (trad.) Australian Greenhouse Office Parkes, ACT. 76 p. No. 31.

[16] Corporación ganadera (CORFOGA). 2000. Análisis del censo ganadero 2000. San José, Costa Rica, 13 p.

[17] Eusse, JB. 2003. Pastos y forrajes tropicales producción y manejo. Agro-Ideagro, A (ed.). Colombia. 700 p.

[18] Di Rienzo J. A., Casanoves F., Balzarini M. G., Gonzalez L., Tablada M., Robledo C. W. (2008). InfoStat, versión 2008, Grupo InfoStat, FCA, Universidad Nacional de Córdoba, Argentina.

[19] Oksanen J, Blanchet FG, Friendly M, Kindt R, Legendre P, McGlinn D, Minchin PR., O'Hara R. B., Simpson GL., Solymos P, Stevens H M., Szoecs E, Wagner H. 2018. Community Ecology Package Consulted 10 May. 2018. Retrieved from https://cran.r-project.org, https://github.com/vegandevs/vegan

[20] Velasco-Fuenmayor, J; Ortega-Soto, L; Sánchez-Camarillo, E; Urdaneta, F. 2009. Influence Factors on the Current Technological Level in the Dual-Purpose Cattle Farms Located in the State of Zulia, Venezuela. _Revista Científica, FCV-LUZ / Vol. XIX, № 2, $187-195$.

[21] Cannavoa, P; Sansoulet, J; Harmanda, J-M; Siles, P; Dreyerd, E; Vaasta, P. 2011. Agroforestry associating coffee and Inga densiflora results in complementarity for water uptake and decreases deep drainage in Costa Rica. Agriculture, Ecosystems and Environment (140):1-13. 
[22] Benegas, L; Ilsted, U; Roupsard, O; Jones, J; Malmer, A. 2014. Effects of trees on infiltrability and preferential flow in two contrasting agroecosystems in Central America. Agriculture, Ecosystems and Environment(183):185- 196.

[23] Ong, C; Kho, R. 2015. A framework for quantifying the various effects of tree-crop interactions. Tree-crop interactions. Agroforestry in a Changing Climate. CAB International, Wallingford (2nd edition):1-23.

[24] Gustad, G; Dhillion, SS; Sidibé, D. 2004. Local use and cultural and economic value of products from trees in the parklands of the municipality of Cinzana, Mali. Economic Botany 4(58):578-587.

[25] Instituto Nacional de Bosques (INAB ${ }_{b}$ ). 2018. PINPEP. Guatemala, Guatemala. Consulted 21 May.2018. Retrieved from http://186.151.231.170/inab/index.php/45-serviciosinab/120-pinpep

[26] Instituto Nacional de Bosques (INAB). 2018a. PINFOR. Guatemala, Guatemala. Consulted 21 May. 2018. Retrieved from http://186.151.231.170/inab/index.php/45-serviciosinab/74-pinfor

[27] Larrazábal, LB; Oliva, E; Ibrahim, M; Detlefsen, G. 2009. Programa de Incentivos Forestales (PINFOR) de Guatemala. In Sepúlveda, C; Muhammad, I (eds.). Políticas y sistemas de incentivos para el fomento y adopción de buenas prácticas agrícolas: como una medida de adaptación al cambio climático en América Central Turrialba, Costa Rica. p. 231-248.

[28] Australian Government Department of Agriculture, Fisheries and Forestry. 2003. Farm Forestry's Role. Australia. 1-16 p. Consulted 21 May. 2018. Retrieved from http://www.agriculture.gov.au/SiteCollectionDocuments/forest ry/plantation-farm/ffrole.pdf

[29] Ibrahim, M; Chacón, M; Cuartas, C; Naranjo, J; Ponce, G; Vega, P; Casasola, F; Rojas, J. 2006. Almacenamiento de carbono en el suelo y la biomasa aérea en sistemas de usos de la tierra en paisajes ganaderos de Colombia, Costa Rica y Nicaragua. Revista de Agroforestería en las Américas. 45:27-36.

[30] Harvey, CA; Villanueva, C; Esquivel, H; Gómez, R; Ibrahim, M; López, M; Martínez, J; Muñoz, D; Restrepo, C; Saénz, JC; Villacís, J; Sinclair, F. L. 2011. Conservation value of dispersed tree cover threatened by pasture management. Forest Ecology and Management 261:1664-1674.

[31] Harvey, CA; Villanueva, C; Ibrahim, M; Gómez, R; López, M; Kunth, S; Sinclair, F. L. 2008 . Productores, árboles y producción ganadera en paisajes de América Central: Implicaciones para la conservación de la biodiversidad. In Harvey, CA; Sáenz, JC (eds.). Evaluación y conservación de biodiversidad en paisajes fragmentados de Mesoamérica Heredia, Costa Rica. p. 197-224.

[32] Villacis, J; Harvey, C. A; Ibrahim, M; Villanueva, C. 2003. Relaciones entre la cobertura arbórea y el nivel de intensificación de las fincas ganaderas en Rio Frio, Costa Rica. Agroforestería en las Américas: 10:9-16.

[33] de Sousa, K; Detlefsen, G; Tobar, D; Melo, Ed; Filho, V; Casanoves, F. 2017. Population dynamic and management of Pinus oocarpa and Tabebuia rosea within silvopastoral systems in Central America. Agroforestry Systems. 91:11191127. Consulted 10 Jun. 2018. doi https://doi.org/10.1007/s10457-016-9988-x

[34] Muñoz, D; Harvey, CA; Sinclair, FL; Mora, J; Ibrahim, M.
2003. Conocimiento local de la cobertura arbórea en sistemas de producción ganadera en dos localidades de Costa Rica. Revista de Agroforestería en las Américas 10(39-40):61-68.

[35] Harvey, CA; Villanueva, C; Villacís, J; Chacón, M; Muñoz, D; López, M; Ibrahim, M; Gómez, R; Taylor, R; Martínez, J. Navas, A; Sáenz, J; Sánchez; Medina, A; Vílchez, S; Hernández, B; Pérez, A; Ruiz, F; López, F; Lang, I; Sinclair, F. L. 2005. Contribution of live fences to the ecological integrity of agricultural landscapes. Agriculture, ecosystems \& environment 111(1):200-230.

[36] Harvey, CA; Guindon, C. F; Haber, W. A; DeRosier, D. H; Murray, K. G. 2008 a. La importancia de los fragmentos de bosque, los arboles dispersos y las cortinas rompevientos para la biodiversidad local y regional: El caso de Monteverde, Costa Rica. In Harvey, CA; Sáenz, JC (eds.). Evaluación y conservación de biodiversidad en paisajes fragmentados de Mesoamérica Heredia, Costa Rica. p. 288-325.

[37] Villanueva, C; Detlefsen, G; Casasola, F. 2018. Potencial de los sistemas silvopastoriles en la mitigación al cambio climático y en la generación de múltiples beneficios en fincas ganaderas de Costa Rica. Turrialba, Costa Rica. 61 p. No. 87.

[38] Chacón León, M; Harvey, CA. 2008. Contribución de las cercas vivas a la estructura y la conectividad de un paisaje fragmentado en Rio Frio, Costa Rica. In A, HC; C., SJ (eds.). Evaluación y conservación de la biodiversidad en paisajes fragmentados de Mesoamérica. Heredia, Costa Rica. p. 225-248.

[39] Camargo, J. C; Ibrahim, M; Somarriba, E; Finegan, B; Current, D. 2000. Factores ecológicos y socioeconómicos que influyen en la regeneración natural de laurel en sistemas silvopastoriles del trópico húmedo y subhúmedo de Costa Rica. Agroforestería en las Américas. 7 (26): 46-49.

[40] Bautista-Tolentino, M; López-Ortíz, S; Pérez-Hernández, P; Vargas-Mendoza, M; Gallardo-Lopez, F; Gómez-Merino, FC. 2011. Agro and Silvopastoral system in the community El Limón, Paso de Ovejas, Veracruz, México. Tropical and Subtropical Agroecosystem. 14:63-76

[41] León, P. 2010. Analysis of forest financing in Guatemala. Ciudad Guatemala, Guatemala. Consulted 20 Ago.2018. Retrieved from http://www.un.org/esa/forests/pdf/aheg/aheg1/Guatemala_case _study.pdf

[42] Instituto Nacional de Bosques (INAB). 2017. Reglamento de la ley de fomento al establecimiento, recuperación, restauración, manejo, producción y protección de bosques en Guatemala. Diario de Centro América, Guatemala, Guatemala; 25 ago.:86

[43] Villanueva, C; Tobar, D; Ibrahim, M; Casasola, F; Barrantes, J; Arguedas, R. 2006. Arboles dispersos en potreros en fincas ganaderas del Pacifico Central de Costa Rica. Agroforestería en las Américas 45:1-9.

[44] Ramírez, IAB. 2012. Efecto de la cobertura arbórea sobre el movimiento, comportamiento y preferencia de árboles por vacas lecheras en Rivas, Nicaragua. Tesis Msc. Turrialba, Costa Rica, CATIE. 62 p.

[45] García, FC; Ibrahim, M. 2013. Los árboles en los potreros para la reducción del estrés calórico del ganado en los trópicos. In Sánchez, d; Villanueva, C; Rusch, GM; Ibrahim, M; DeClerck, $\mathrm{F}$ (eds.). Estado del recurso arbóreo en fincas ganaderas y su contribución en la sostenibilidad de la producción en Rivas, Nicaragua. Turrialba, Costa Rica. p. 36-41. 